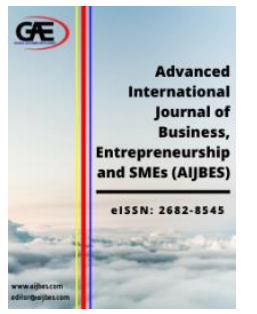

\author{
ADVANCED INTERNATIONAL JOURNAL OF \\ BUSINESS, ENTREPRENEURSHIP AND SMES \\ (AIJBES) \\ www.aijbes.com
}

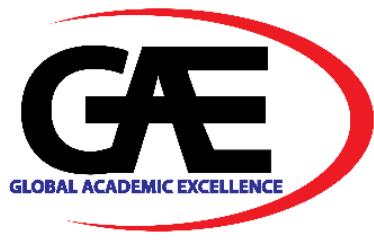

\title{
THE PURCHASE INTENTION'S DRIVER OF PRIVATE LABEL BRANDS FROM THE HYPERMARKET STANDPOINT
}

\author{
Ima Ilyani Ibrahim ${ }^{1 *}$, Nur Hazirah Mohammad Yatim² \\ 1 Faculty of Business and Management, Universiti Teknologi MARA, Perlis Branch, Arau Campus, Malaysia \\ Email: ilyani686@uitm.edu.my \\ 2 Faculty of Business and Management, Universiti Teknologi MARA, Perlis Branch, Arau Campus, Malaysia \\ Email: nurhazirahyatim@gmail.com \\ * Corresponding Author
}

\section{Article Info:}

Received date: 14.07 .2020

Revised date: 03.09.2020

Accepted date: 07.09.2020

Published date: 10.09.2020

\section{To cite this document:}

Ibrahim, I. I., \& Yatim, N. H. M. (2020). The Purchase Intention's Driver of Private Label Brands from the Hypermarket Standpoint. Advanced International Journal of Business, Entrepreneurship and SMEs, 2 (5), 01-14.

DOI: $10.35631 /$ AIJBES.25001.

\begin{abstract}
:
These days, the consumer is starting to make changes in their buying behavior since the income is overwhelmed due to the economic pressure. Subsequently, the Private Label Brands (PLBs) are offering lower prices compare to National Brands (NB), and cause the consumer started to purchase PLBs to manage their expenses. The determination of this research is to study the Purchase Intention of Private Label Brands (PLBs) and identifies the predictors of Purchase Intentions for the store brands since there are shortcomings of previous studies regarding PLBs' main factors. The aims are to observe the relationship between Purchase Intention of Private Label Brands (PLBs) and Perceived Price, Perceived Quality, Perceived Value, and Perceived Risk. Primary data was collected through self-administered questionnaires to the respondents in Northern areas using mall intercepts. From the finding, there are significant and influential relationships between the DV and IVs. The results will certainly provide extensive information where retailers should focus to obtain a strategic competitive advantage by adding value to its products and services or reducing its own costs more effectively than its rivals in the industry.
\end{abstract}

Keywords:

Purchase Intention, Perceived Price, Perceived Quality, Perceived Value, Perceived Risk

\section{Introduction}

Tesco and Giant brand products (refer to Figure 1) are part of the Private Label Brands (PLBs) that owned by the retailer or wholesaler which can only found in their retail stores and became one of the exclusive products. PLBs are trying to be matching up and replicate of novelty from 
National Brands (Kumar and Steenkamp, 2007). Initiated study by Blazeska (2013), the four main stages evaluation of PLBs identified that the first stage represented PLBs had low quality at the low price. They had same name as a retailer or retail chain but did not have any element of brand identity as design, packaging, colour, slogan, and logo. This led to a reduced amount of purchasing by the consumer due to non-familiarity toward the brands. Second, PLBs gained some elements of brand identity like their own name, symbol, colour, design and sometimes slogan. The innovation helps the products to a certain level of quality and still in low competitive price which is National Brands (NB) still cannot be able to compete with PLBs. Third, PLBs had improved its quality with the reasonable price that still lower than NB. The price remains to be one of the aims why PLBs can capture the customer attention as their products choice. The last stage of evolution of PLBs regarding the management of private brand in some products types. Although the PLBs were limited to commodity-based products such as tea and sugar, it was perceived as low quality and unbranded alternatives to National Brands. Currently, PLBs are substantial players in many markets around the world, achieving impressive success in European countries, especially where penetration rates in terms of dollar share rates are typically in the 30-45 percent range (Nielsen, 2018). The successful of PLBs effort of multitier store brands now exist (Hokelekli et al. 2017; Ter Braak et al., 2014). Hence, the objective of this study was to examine the predictors that influence the purchase intention toward PLBs and help retailers in taking appropriate action to increase brand awareness as well as attract more consumers in purchasing PLBs among Malaysian since PLBs value share is only 2\% in Malaysia; compared to 8.1\% in Singapore and 45\% in Switzerland (Nielsen, 2014).

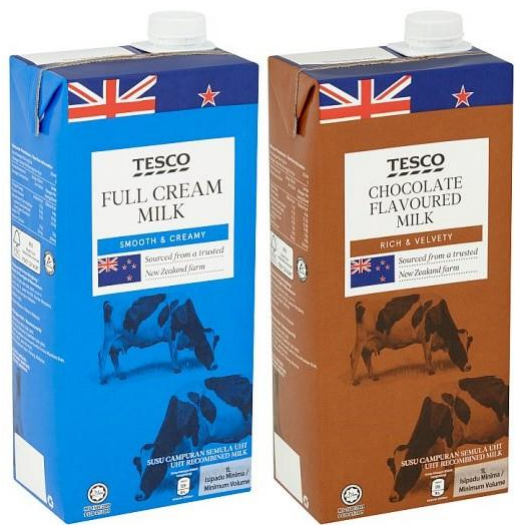

Tesco Full Cream Milk \& Chocolate Flavoured Milk

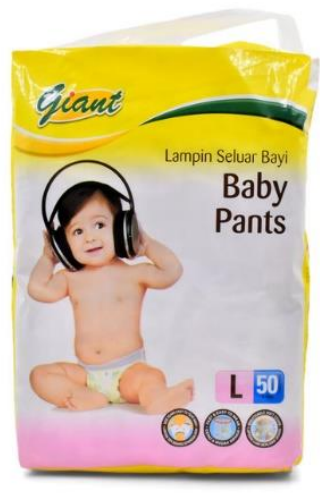

Giant Baby Pants

Figure 1: Example of Tesco and Giant Store Brand Products

(Source: Google Search, 2020)

\section{Literature Review}

\section{Private Label Brands}

Founded by Gonzalez (2006), Private Label Manufacturers Association (PLMA) defines it as private label products is all merchandize that being sold under retailer's brand. PLBs are often refer as own labels, own brands, in-house brand, store brands, retail brands, or distributor brands (Satriya, R., 2013; M. Raja \& Dr. M. I. Saifil Ali, 2014). In addition, PLBs are not only produced by retailers, but it also can be produced by manufacturers for retailers with the purpose to achieve economies of scale in production, distribution, and also excess the capacity 
(Baltas, 1997). On the other hand, by that aim it can help the retailers to introduce and develop PLBs as a strategy to increase customer loyalty as well as positioning the brands which can lead to more profitability by improving its store's image (Pavel, 2007). The main purpose of a PLBs is to strengthen a retailer's bargaining position in comparison with national retailers and raise their brand images in the marketplace (Dunne, Lusch, \& Carver, 2014).

\section{Purchase Intention toward Private Label Brands}

According to Kim J. (2015), purchase intention will come when the consumer have willingness to purchase products. Purchase intention determines the likelihood that a consumer will purchase a product and a consumer is said to be more willing to purchase when there is high purchase intention (Chi, Yeh, \& Tsai, 2011). Hence, perception is very important in defining purchase intention (Tih \& Lee, 2013). Based on study Huang at el. (2006), consumers' attitudes towards product were measured by their acceptance and willingness to purchase. Acceptance of a product does not indicate a willingness to purchase it (Huang et al, 2006; Font, Gil, \& Traill, 2008). Therefore, it is importance to understand the factors that influence consumer willingness to purchase a product. Ability to purchase depends on objective factors, while willingness to purchase stands for the subjective factors (Celik et al, 2010).

\section{Perceived Price}

According to Kotler (2012), price is amount of money charged for a product or service. Price can be categories in objective price and perceived price. Objective price, which is the actual price that consumer pays for a product, and Perceived Price, which is the price determined by consumer (Zeithaml, 1988). Dickson and Sawyer's study (as cited in Veale, 2007) found that consumers could not remember how much they paid for a product but only considered about the price after the purchase decision. This signifies that consumers have low levels of knowledge about products. This is also supported by Veale (2007) that state the consumers will purchase product based on a price scale, where their perception low price for the low-quality product and high price for high quality. Low priced products are made by lower quality raw materials in order to maintain the profit margins (Li \& Green, 2011). The dimension of perceived price is price consciousness.

\section{Price Consciousness}

Price perception may become prominent for the since they conscious toward the price of product. The concept of price consciousness has been used in many studies with plenty of cognitive condition associated with the price. Price consciousness can be explained as the degree to which the consumer focuses exclusively on paying product that at the lower prices (Lichtensteion et al. 1993). This study also supported by Jin \& Sternquist (2003), price consciousness is referred toward the buyer behavior during the economic recession. This is because, since economic in bad condition, income per capita will decrease and the consumer need to make some changing in their purchase decision which make them became more price sensitive. This supported by Moore et al. (2013), the consumer will be seeking for low price product during the economic recession in order to managing their expenses.

\section{Perceived Quality}

According to Kotler (2012), quality as entire feature and characteristics of a product or service that will satisfy the implied needs of the product and services. Besides that, Perceived quality is different from objective quality or actual quality because it constitutes the subjective judgment of the product (Kristensen, 2014). Olshavsky (as cited in Findlay, 2002) views 
quality as "a form to evaluate overall performance of a product". In other word, quality is based on the consumer perception toward the product. Consumers may perceive a product based on both tangible and intangible characteristics, such as performance, features, reliability, conformity, durability, service ability and aesthetics (Vantamay, 2007). Grunert (2010) mentioned that, quality is something intangible that can be perceived before and after the purchase. There are four dimension of perceived quality which is performance, features, conformance, and reliability.

\section{Performance}

Performance is a primary operating characteristic of the product. It also can be referred to contention between customers and suppliers. The performances of product influence the profitability and the reputation of the end-user. In example, for an automobile, these could include traits like acceleration, handling, cruising speed, and comfort (Garvin, 1987).

\section{Features}

Features can be referred to additional characteristics that enhance the appeal of the product and services to the user. Feature may be highly visible but not necessary primary. Moreover, the distinction between performance and feature is one of relative importance to a particular customer when choosing the product (Garvin, 1987).

\section{Conformance}

All product and services involve specifications of some sort. When the products are developed, the specification are set, and the target is the materials that being used to produce the product. On the other hand, this is a traditional, manufacturing-oriented view of quality. It can be explained as degree of product's design and operating characteristics that are match with the established standard. In example, failures include lost mail, delays in airline departures, incorrect bank statements, misapplied label and shoddy construction (Garvin, 1987).

\section{Reliability}

In this study, reliability indicated the degree of product to perform as expected and for which the failure to perform is small. Reliability include such things as mean time of the first failure, mean time between failure, and failure per unit of time (Garvin, 1987). When the product can perform as what the customer need, it will increase the purchase intention toward the product.

\section{Perceived Value}

According to Ziethml (1988), customer perceived value can be determined through various elements such as satisfaction, acceptable product or service for the paid price, low price in comparison with the competitors and what the customer get for what they give in exchange. Customer perceived value is the customer's evaluation of all the benefits and the cost of an offering (Rini \& Andradea 2012). Perceived value in marketing also defined as the psychological evaluations and feelings of consumers about the perceived benefits by purchase the product (Ali F.O., 2013). This is supported by Chi, Yeh \& Tsai (2011) claimed that perceived value is the main factors in customer decision process and customer will purchase a product when they perceived the product contains the high value. Generally, increase in perceived quality usually leads to increase in perceived value (Korde A.P., 2010). According to Li \& Green's study (2011) observes that there are two concepts of consumer perceived value which is consumer perceived value is an outcome from the perception of consumer before he makes a purchase (expectation), evaluation during the transaction (expectation versus 
received), and post-purchase assessment (expectation versus received), and consumer perceived value involves a divergence between the benefits received (consumer's desired value) and sacrifices given (monetary and non-monetary considerations). There are two dimension of perceived value which is product related value and personal related value.

\section{Product Related Value}

Based on this research, product related value can be referred as the customer perspective that product is the source of value. Since the product is the main focus in purchase activities, the consumer will make purchases based on product that can give benefits toward them. In addition, it can be classified into two fundamental perspectives of customer needs which the need for product function and need for the pleasure of using the product. The customer will see the product as the tool that has function either to meet their needs or to make the task easier (Joiner, 1994; Thompson, 1998).

\section{Personal Related Value}

Personal related value is strongly related to the self-concept held by the customer. Every customer has their own perceived values; thus, it influences their perception of value towards a product (Oliver, 1996; Huber et al., 2001). In the first perspective, the customers value the product based on how fits it is with their characteristic.

\section{Perceived Risk}

According to Bauer (1960), perceived risk and its determinants, namely, uncertainty and negative consequences. Perceived risk is a "multidimensional phenomena" which can be segmented into various different risk components (Mitchell, 1998). There are five dimensions of perceived risk which is functional risk, physical risk, financial risk, social risk, and psychological risk.

\section{Functional Risk}

Functional risk is described as the uncertainty that the outcome of a product purchase will not meet consumer expectations (Agarwal \& Teas, 2001). Besides that, it is also expressed as a performance risk as it demonstrates the consumer's fear that a product will not perform to its promised abilities. In addition, the others factor that will increase the functional risk is when the consumer search for information toward the product or based on the actually experiences by other consumers (Glynn \& Chen, 2009).

\section{Physical Risk}

Physical risk is the possibility that the product may harm the consumer and others in physical sense. In other words, the consumer fear that certain products can damage their health or physically injure their person (Durmus B. et al., 2017). All health related and physical concerns with regard to the use of a product are included in this risk group.

\section{Financial Risk}

Based on study by Durmus (2017), stated that financial risk can be conclude as the product does not perform to expectations which can lead to unsatisfied of consumer by purchasing the product. The consumer will be perceived high risk toward the product because not worth for money. Furthermore, financial risk depends on the price levels of the product category (Zielke \& Dobbelstein, 2007). As studied by Lijander et al. (2009), Zielke \& Dobbelstein (2007), Mieres et al. (2006) and Sweeney et al. (1999) seem to agree that the price quality association 
drive the consumers in increasing of perceived financial risk. It would appear that many consumers prefer to pay a premium for the assurance of quality in order to avoid any financial risk (DelVecchio, 2001). On the other word, financial risk may consider as the risk will come after the purchases either it is good purchases or bad purchases which the consumer will make evaluation after had purchase the product.

\section{Social Risk}

A possible perceived loss of image or status through the purchase of a particular brand or product is referred to as social risk (Zielke \& Dobbelstein, 2007). Social risk is also defined as the extent to which a customer believes. Social risk is an important element of perceived risk as it takes into account how society influences a consumer's decision (Durmus at el. 2017).

\section{Psychological Risk}

Psychological risk can be defined as associated with the consumption of the product and its symbolic aspects, such as beliefs and status (Batra and Sinha, 2000; DelVecchio, 2001). Psychosocial risk exists to the extent that the consumer believes that will be negatively evaluated due to product (brand) choice. Nonetheless, not all products are consumed in public situations, other people might not be aware that someone possesses and uses a certain product, when it is not highly visible to others (Bearden and Etzel, 1982).

\section{Theoretical Framework}

Figure 2 illustrate the theoretical framework based on covered literature reviews:

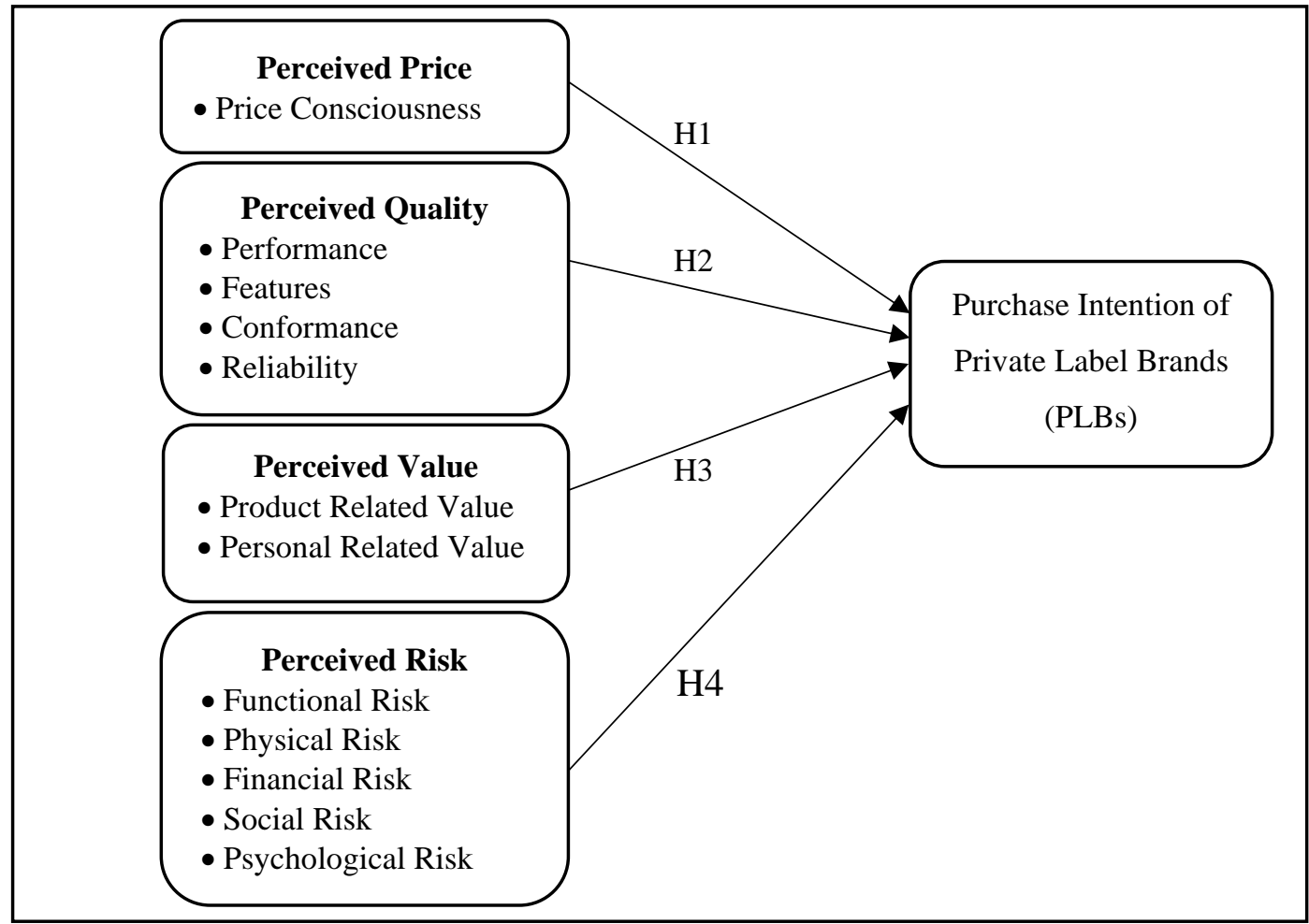

Figure 2: Purchase Intention of Private Label Brands (PLBs)

Source: Yoo et al., (2000); Dodds et al., (1991); Jin \& Sternquist (2003); Mieres et al., (2006); Richardson et al. (1996) 


\section{Hypothesis}

H1: There is a positive influence between perceived price and purchase intention toward private label brands

$\mathrm{H} 2$ : There is a positive influence between perceived quality and purchase intention toward private label brands.

H3: There is a positive influence between perceived value and purchase intention toward private label brands.

$\mathrm{H} 4$ : There is a negative influence between perceived risk and purchase intention toward private label brands.

\section{Methodology}

In order to complete this research, the primary and secondary data were used as sources. The length of data collection period is five weeks which is $10^{\text {th }}$ May 2019 until $1^{\text {st }}$ June 2019. In this study, the questionnaires with five-point Likert Scale were used and distributed to the public using mall intercept technique. The respondents were access at numerous hypermarkets, shopping malls and supermarkets. The process involved identifying the prospects, approached them and administering a survey on the spot. The convenience sampling techniques helps the researcher to choose the right target sample since respondents were available to be interviewed or willing to participate at the moment in succession the survey. The instrument used for this study were adapted from various sources. This questionnaire comprises of 25 questions including demographics (refer Table 1).

Table 1: The Source for Questionnaires for Each Variables

\begin{tabular}{llc}
\hline \multicolumn{1}{c}{ Variable } & \multicolumn{1}{c}{ Source } & No. of Item \\
\hline Purchase Intention & Jin and Sternquist (2003) & 4 \\
Perceived Price & Yoo et al. (2000) & 2 \\
Perceived Quality & $\begin{array}{l}\text { Jin and Sternquist (2003); Mieres et al. } \\
\text { (2006); Yoo et al. (2000) }\end{array}$ & 6 \\
Perceived Value & $\begin{array}{l}\text { Dobbs et al. (2014) } \\
\text { Richardson et al. (1996); Mieres et al. } \\
\text { Perceived Risk }\end{array}$ & 5 \\
\hline
\end{tabular}

\section{Findings}

Table 2: Demographic Analysis

\begin{tabular}{llcc}
\hline \multicolumn{1}{c}{ Variable } & \multicolumn{1}{c}{ Categories } & Frequency $(\mathrm{N})$ & Percentage $(\%)$ \\
\hline Gender & Male & 154 & 46.7 \\
& Female & 176 & 53.3 \\
Marital status & Single & 156 & 47.3 \\
& Married & 169 & 51.2 \\
& Others & 5 & 1.5 \\
\multirow{5}{*}{ Job position } & Employed & 282 & 85.5 \\
& Unemployed & 22 & 6.7 \\
& Student & 26 & 7.9 \\
\hline
\end{tabular}




\begin{tabular}{llcc} 
Types of job & Government & 136 & 41.2 \\
& Private & 124 & 37.6 \\
& Others & 70 & 21.2 \\
Income & Below RM1000 & 67 & 20.3 \\
& RM1000 - RM5000 & 228 & 69.1 \\
& RM5000- RM10000 & 3 & 10.6 \\
\hline
\end{tabular}

Table 2 shows that the total numbers of respondents were 330. Approximately, out of 330 respondents, $53.3 \%$ (176) were female with the majority of the respondents are married. Most of the respondents are employed in government sector, with the level of income at the range of RM1000 to RM5000 (69.1\%).

Table 3: Correlation Analysis

\begin{tabular}{lllllll}
\hline Variable & $\mathrm{B}$ & $\mathrm{C}$ & $\mathrm{D}$ & $\mathrm{E}$ & $\mathrm{F}$ & $\mathrm{SIG}$ \\
\hline $\begin{array}{l}\text { Purchase intention } \\
\text { toward Private Label }\end{array}$ & 1 & & & & & .000 \\
$\begin{array}{l}\text { Brands (PLBs) } \\
\text { Perceived Price }\end{array}$ & $.498^{* *}$ & 1 & & & & .000 \\
Perceived Quality & $.715^{* *}$ & $.415^{* *}$ & 1 & & .000 \\
Perceived Value & $.637^{* *}$ & $.366^{* *}$ & $.706^{* *}$ & 1 & & .000 \\
Perceived Risk & $-.509^{* *}$ & $-.280^{* *}$ & $-.518^{* *}$ & $-.605^{* *}$ & 1 & .000 \\
\hline
\end{tabular}

**Correlation is significant at the 0.01 level (2-tailed)

**Correlation is significant at the 0.05 level (2-tailed)

From Table 3, it shows there is a significant and positive correlation between those IVs and DV. However, two of the IVs [Perceived Value $(\mathrm{r}=.637, \mathrm{p}=.000)$ and Perceived Risk $(\mathrm{r}=-.509$, $\mathrm{p}=.000)]$ show a substantial relationship with the DV. Only one variable has strong relationship with Purchase Intention toward Private Label Brands (PLBs) which is Perceived Quality $(\mathrm{r}=.715, \mathrm{p}=.000)$. While for Perceived Price $(\mathrm{r}=.498, \mathrm{p}=.000)$ create a moderate relationship towards the DV.

Table 4: Multiple Regression Analysis

\begin{tabular}{lcc}
\hline Variable & Unstandardized and Coefficient Beta & Sig \\
\hline Perceived Price & .254 & .000 \\
Perceived Quality & .527 & .000 \\
Perceived Value & .217 & .001 \\
Perceived Risk & -.106 & .014 \\
\hline F change & 119.149 & \\
R square & .595 & \\
Adjusted R square & .590 & \\
Durbin Watson & 1.543 & \\
\hline
\end{tabular}

$* * \mathrm{p}<.05$ 
Table 4 shows the Regression Analysis describe the regression result of the four IVs with the DV. Linear Regression analysis will help to recognize whether there is significant relationship between dependent and independent variables. In addition, it will test the hypothesis for the factors that impact of Purchase Intention toward Private Label Brands (PLBs). From the finding, Perceived Quality $(\beta=0.527, p=0.000)$ had been determined to have the strongest relationship compared to Perceived Price $(\beta=0.254, \mathrm{p}=0.000)$ and Perceived Value $(\beta=0.217$, $\mathrm{p}=0.001)$. On the other side, Perceived Risk $(\beta=-0.106, \mathrm{p}=0.014)$ show a negative influence towards the DV. This is because consumers may perceive that PLBs consists of higher risk than other familiar brands. However, it may constitute consumers to continue purchasing PLBs products due to other three factors. The F change (119.149) is acceptable and strong. It was indicated that Purchase Intention toward Private Label Brands (PLBs) was explained by the independent variable 59\% while the rest $41 \%$ was explained by the other variables that were observed. As can be seen from the table, the result of Durbin Watson is 1.543 which indicates the result is free errors since the measure of Durbin Watson is good at above 1.5. As conclusion, the entire hypothesis was accepted since there is a significant influence and relationship between the IVs and DV.

\section{Discussion and Conclusion}

Refer to the objective, this study aims to determine the predictors that influence the purchase intention of Private Label Brands (PLBs). Therefore, based on the findings, the three IVs (Perceived Price, Perceived Quality and Perceived Value) have positive influence toward Purchase Intention of Private Label Brands (PLBs). However, Perceived Risk is negatively influence on Purchase Intention toward Private Label Brands (PLBs). In this research, perceived price of PLBs is examined by asking the respondents about the different product price between NB and PLBs also the average of market price in general. On average, most of respondent are agreed that the price is an important criterion when they want to make purchase decision. In addition, they also have similar opinions that spending more time looking for lowest price in order to managing their expenses during economic condition are worth it. The consumer started to compare the price of PLBs with other brands and try to find the cheapest products in the market when they do their shopping. Consumers are more likely to purchase PLBs because they are cheaper and reasonably priced compare to other brands.

According to Kakkos et al. (2014), Perceived Quality is about consumers relying on their current consumption experience to judge the product's quality or performance. Finding from the study had identified the respondents seem to judge the quality of Private Label Brands (PLBs) based on their perception and also based on others consumer experiences. They agreed that quality is an important criterion when they make a purchase decision and the quality of product increases the value of brand in their perception. When consumers perceive a product as high quality, they will also view that particular brand as high which indicate lower risk. However, the respondents do not agree that Private Label Brands (PLBs) have higher quality than other competing brands. On average, they perceived low-priced Private Label Brands (PLBs) as low-quality products and this is corresponded to the past study by Dodds et al. (1991) which states that Perceived Price has significant influence on perceived quality. Overall, respondents perceived Private Label Brands (PLBs) as low-quality products since there is immense differ in terms of quality between PLBs and NB.

Additionally, it was found that Perceived Value has significant impact on Purchase Intention toward Private Label Brands (PLBs). This is corresponding to past studies (Liao \& Hsieh, 
2013; Thanasuta, 2015) which states that consumers may still prefer established and reputable brand instead of value-for-money. Consumer generally will shop around for lower priced products and make sure that the product provides value-for-money before they purchase a product. Instantaneous, respondents stated that they will compare prices of PLBs with other competing brands to make sure that they get the best value for money.

Meanwhile, Perceived Risk negatively influence toward Purchase Intention toward Private Label Brands (PLBs). Based on the results, respondents agreed that they will choose products carefully before they make a purchase decision. Furthermore, respondents also perceive Private Label Brands (PLBs) to have higher risk due to its low price and quality. They are worried that PLBs do not work and function as it should be. This is corresponding to Dunn, Mark, Patrick and Geral's study (as cited in Selvakumar \& Varadharajan, 2013) which stipulated that consumers view PLBs as the riskiest on performance measures. Moreover, it is also found out that the respondents in this research study view PLBs as risky products on financial measures, since they feel uncertain and worry that PLBs do not worth the money. In addition, the respondents also doubt and feel suspicious with the ingredients and materials used to manufacture the PLBs which is physical risk that they are worried about their health. However, the respondents do not worry that they will receive negative criticism if they purchase PLBs. This shows that social risk has no effect on Purchase Intention toward Private Label Brands (PLBs). In short, the research results show that respondents perceive PLBs as risky products in terms of performance and financial measures, but least risky on social measures. In a nutshell, retailers should focus more on quality of PLBs in order to attract more consumers and boost the sales of PLBs.

Thus, there are some practical insights for retailers that could be implement in order to increase consumer's purchase propensity for Private Label Brands (PLBs). For instance;

\section{- Focus in pricing strategies}

The Private Label Brands (PLBs) advantages is low price, which are more likely to attract price-concerned consumers. Retailers should observe what price are competitors charging and either raise or lower the PLBs prices based on the company goals. For example, provide monthly promotion of PLBs product. However, retailers are advised to not randomly increase prices of PLBs as most of the PLBs consumers are price conscious.

\section{- Improving on quality}

Retailer should at best continue to improve the quality of PLBs without increase in cost to raise consumers' acceptance and the familiarity toward Private Label Brands (PLBs). By offering PLBs at affordable price and acceptable quality, retailers will be able to capture more quality-conscious and value-conscious consumers as well as boost the PLBs sales.

\section{- Emphasis on Informative and Persuasive Advertising}

The company should come out with Informative and Persuasive Advertising which can assist the consumer to better understanding about the product use, benefits and also aware about the product. The more information gains by the consumer about the PLBs product, the lesser risk that will influence them to purchase PLBs. Therefore, hiring the right ambassador may help to enhance the sales of PLBs.

- Increase consumer loyalty through membership program

To increase the perceived value of consumer, the company also may implement membership program, such as when consumer buying PLBs, they can earn 3x point per RM1 purchases where the collected point can be exchange with another PLBs' product according to term and condition. 


\section{Acknowledgement}

The appreciation goes to Nur Hazirah Mohammad Yatim for completing the thesis and graduate with honors.

\section{References}

Agarwal, S. a. (2001). .Perceived value: mediating role of perceived risk . Journal of Marketing Theory and Practice, 1-14.

Ali, F. O. (2013). An examination of the relationship between physical environment, perceived value, image, and behavioural intentions. Journal of Hotel and Tourism Management, 9-26.

Baltas, G. (1997). Determinants of Store Brand Choice: A Behavioral Analysis. Journal of Product and Brand Management, 315-324.

Batra, R. S. (2000). Consumer-level factors moderating the success of private label brands. Journal of Retailing , 175-191.

Bauer, R. (1960). Consumer behaviorasrisk taking", in Hancock, R.S. (Ed.), DynamicMarketing for aChanging World,. American Marketing Association, Chicago, 389-398.

Bearden, W. E. (1982). Reference group influence on product and brand purchase decisions. . Journal of Consumer Research 9,, 183-194.

Beril Durmus, Y. U. (2017). The effect of perceived risk on online shopping through trust and WOM. Academicsera 6th International Conference, (pp. 12-17). New York .

Blazeska.D. (2013). Brand Management. Faculty of Economics, European University Republic of Macedonia, 195.

Celik, S. A. (2010). The relationship between consumer confidence and financial market variables in Turkey during global crisis. Journal Economics, 1-17.

Chi, H. Y. (2011). The influences of perceived value on consumer purchase intention: The moderating effect of advertising endorser. Journal of International Management Studies, 1-6.

DelVecchio, D. (2001). Consumer perceptions of private label quality: The role of product category characteristics and consumer use of heuristics. Journal of Retailing and Customer Services 8, 239-249.

Dodds, W. M. (1991). The effects of price, brand and store information on buyers' product evaluations. Journal of Marketing Research, 307-319.

Dunne, P. M. (2014). Retailing . Journal of Retailing .

Findlay, A. (2002). Retailing: Critical concepts. London: Routledge.

Font, M. G. (2008). Consumer acceptance, valuation and attitudes towards genetically modified food: Review and implications for food policy . Journal Food Policy, 99111.

Garvin, D. (1987). Competing on the Eight Dimentions of Quality. : Harvard Business Review.

Glynn, M. S. (2009). Consumer factors moderating private label brand success: futher empirical result. Journal of Retail and Distribution Management , 896-914.

Google.com. (2020). Giant Baby Pants - Google Search. [online] Available at: $<$ https://www.google.com/search?q=giant+baby+pants\&rlz=1C1GCEA_enMY906M Y906\&sxsrf=ALeKk00Up4GRTT5rWBkrDAccNziEKXpi6A:1594488838017\&tbm= isch\&source=iu\&ictx=1\&fir=jfiWa0sdCJabM\%252CEY_8pwyPNJzUOM\%252C_\& vet=1\&usg=AI4_-kQESmdhdGT6--

P0LsUSWF3_kKatwQ\&sa=X\&ved=2ahUKEwig7abm3cXqAhWNF3IKHUrFA8kQ9 
QEwA3oECAoQHA\&biw=1024\&bih=657\#imgrc=jfiWa0sdC-JabM> [Accessed 11 July 2020].

Google.com.

(2020).

[online]

Available

at:

$<$ https://www.google.com/search?q=tesco+chocolate+milk\&tbm=isch\&ved=2ahUKE wiEna7p3cXqAhUwkUsFHWWFBlkQ2cCegQIABAA\&oq=tesco\&gs_lcp=CgNpbW cQARgAMgQIIxAnMgcIABCxAxBDMgQIABBDMgQIABBDMgQIABBDMgQIA BBDMgQIABBDMgQIABBDMgQIABBDMgQIABBDOgIIADoFCAAQsQM6CAg AELEDEIMBUKPIF1iG1Bdg494XaABwAHgAgAGYAogBygaSAQUwLjQuMZgB AKABAaoBC2d3cy13aXotaW1n\&sclient=img\&ei=DPgJX4TnGbCirtoP5YqayAU\& bih=657\&biw=1024\&rlz=1C1GCEA_enMY906MY906\#imgrc=YW4Ewy25Ppx3iM $>$ [Accessed 11 July 2020].

Gonzalez, A. (2006). Canada market development reports -Private label report. Canada: Global Agriculture Information Network.

Grunert, K. (2010). European consumers' acceptance of functional foods. Annals of the New York Academy of Sciences, Vol.1190No.1,pp.166-173.

Hökelekli, G. L. (2017). Private label line proliferation and private label tier pricing: a new dimension of competition between private labels and national brands. Journal of Retailing and Consumer Services, 39-52.

Huang, J. Q. (2006). Awareness, acceptance of and willingness to buy genetically modified foods in urban China. 144-151.

Huber, F. A. (2001). Gaining competitive advantage through customer value oriented management. Journal of Consumer Marketing, , 18(1): 41-53.

Jin, B. \&. Sternquist, B. (2003). The influence of retail environment on price perceptions: An exploratory study of US and Korean students. Journal of International Marketing Review, 643-660.

Joiner, B. (1994). Fourth generation management: The new business consciousness. New York : McGraw-Hill. .

Kakkos, N. T. (2014). Indentifying drivers of purchase intention for private label brands: Preliminary evidence from Greek consumers. International Conference on Strategic Innovative Marketing (pp. 522-528). Madrid, Spain: Procedia- Social and Behavioral Sciences.

Kim, J. (2015, October 21). Retrieved from Understanding consumers online shopping and purchasing behaviors.: https://shareok.org/bitstream/handle/11244/6700/Department\%20of\%20Design, $\% 20$ Housing $\% 20$ and $\% 20$ Merchandising_05.pdf?sequence $=1$

Korde, A. P. (2010). Development, validity and reliability of perceived service quality in retail banking and its relationship with perceived value and customer satisfaction . Managing Global Transitions, 187-205.

Kotler, P. (2012). The role of country of origin in product evaluations: Informational and standard of comparison effects. Upper Saddle River, N.J : Prentice Hall.

Kristense, L. F. (2014, October 27). Retrieved from Consumer's quality perception and willingness to pay for Hugo Prosejito: A new ready to drink product on the Danish market: http://pure/au.dk/portalasbstudent/files/79442221/Master_Thesis_Hugo_Prosejita.pdf

Kumar, N. a. (2007). Private Label Strategy: How to Meet the Store Brand Challenge. Boston, MA: Harvard Business School Press.

Li, M. L. (2011). A mediating influence on customer loyalty: The role of perceived value. Journal of Management and Marketing Research , 1-12. 
Liao, C. \&. (2013). Determinants of consumer's willingness to purchase gray-market smartphones. Journal of Business Ethics, 409-424.

Lichtensteion, D. R. (1993). Price Perceptions and Consumer shopping Behavior . Journal of Marketing, Vol.30, p.234-245.

Lijander, V. P. (2009). Modelling consumer respones to an appereal store brand: Store image as risk reducer. Journal of Retailing and Consumer Services, 90-281.

M. Raja \& Dr. M. I. Saifil Ali (2014). An analysis of consumer perception towards retail brands in Big Bazaar, Chennai . Indian Journal of Applied Research, 13.

Mieres, C. M. (2006). Antecedents of the difference in perceived risk between store brands and national brands. European Journal of Marketing, 61-82.

Mitchell, V. W. (1998). A role of consumer risk perceptions in grocerry retailing . Journal of British Food, 83-171.

Moore, M. K. (2013). Cross cultural Equivalance of Price Perceptions Between US and Polish Consumers. Journal of Retail and Distribution Management, Vol.31 p. 345-358.

Nielsen. (2014). The state of private label around the world: Where it's growing, where it's nit, and what the future holds. New York: Nielson .

Nielsen. (2018). The rise and rise again of private label",. Retrieved from Nielsen: www.nielsen.com/content/dam/corporate/us/en/

Oliver, R. (1996). Varieties of value in the consumption satisfaction response. Advances in Consumer Research, 23: 143-147.

Pavel, C. (2007). Threats and oppurtunities of private labels. Journal of International Business, $120-124$.

Richardson, P. J. (1996). Household store brand proneness: A framework. Journal of Retailing, 159-185.

Rini, S. \& Andradea, P. (2012). The impact of perceived value on customer satisfaction, loyalty, recommendation and repurchase: An empirical study of Spa Industry in Indonesia. Journal of Tourism and Management, 156-160.

Satriya, R. (2013). Integrating effect of consumer perception factors towards private label brands in food and grocery retail sector in Chennai region. Journal of Economics and Management, 1-15.

Selvakumar, J. J. (2013). Study on the growth prospects of private labels to that of national brands in the FMCG retail sector in Coimbatore. International Journal of Economic, Business and Finance, 1 (2), 26-34.

Sweeney, J. S. (1999). The role of perceived risk in the quality value relationship: A study in a retail environment. Journal of Retailing , 77-105.

Ter Braak, A. G. (2014). Taking private labels upmarket: empirical generalizations. Journal of Retailing, Vol. 90, 125-140.

Thanasuta, K. (2015). Thai consumers' purchase decisions and private label brands. International Journal of Emerging Markets, 102-121.

Thompson, H. (1998). Marketing strategies: What do your customers really want? Journal of Business Strategy, 16-21.

Tih, S. \&. (2013). Perceptions and predictors of Consumers' Purchase Intentions for Store Brands: Evidence from Malaysia. Journal of Business and Accounting, 107-138.

Vantamay, S. (2007). Understanding of perceived product quality: Reviews and recommendations. Bangkok: Bangkok University .

Veale, R. (2007, October 17). Retrieved from Investigating the simultaneous influence of intrinsic and extrinsic cues: An examinatuon of the interaction between country of origin, price and selected 
sensoryvariables.:http://digital.library.adelaide.edu.au/dspace/bitstream/2440/38837/8/ 02whole.pdf

Yoo, B. D. (2000). An examination of selected marketing mix elements and brand equity. Journal of the Academy of Marketing Science, 195-211.

Zeithaml, V. (1998). Consumer perceptions of price, quality, and value: A means-end model and synthesis of evidence. Journal of Marketing , 52(3): 2-22.

Zielke, S. a. (2007). Customers willingness to purchase new store brands. Journal of product and brand management , 21-112. 